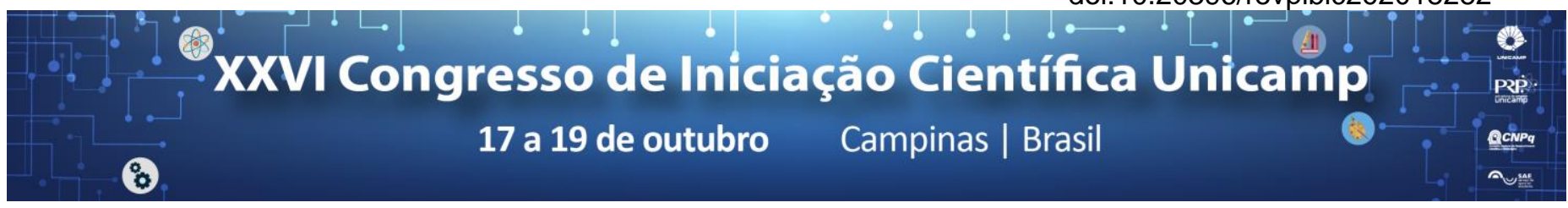

\title{
Adiponectin and proteinuria in normotensive and hypertensive rats.
}

\author{
Carolina Silva*, Filipy Borghi, Camila Morais, Priscila Cristina da Silva, Dora Maria Grassi- Kassisse.
}

\begin{abstract}
Adiponectin is an anti-inflammatory adipokine produced by adipose tissue and its concentration is depressed in obesity and systemic arterial hypertension. Studies have established a relationship between the adiponectin plasma concentration and complications such as obesity and renal diseases. Proteinuria indicates renal dysfunction or infection and has a negative correlation with adiponectin plasma concentrations. The Wistar-Kyoto (WKY) and spontaneously hypertensive rats (SHR) exhibited higher urinary protein concentrations when compared to Wistar rats (WIS). Therefore, this study aimed to evaluated the serum concentrations of adiponectin and its relation to proteinuria in these rats. The results indicate that WKY present a reduction in the adiponectin serum concentration when compared to WIS and SHR. The low production of adiponectin is related to proteinuria and to the heavy weight of these animals. SHR exhibit similar serum adiponectin levels to WIS, suggesting the hypertension as the responsible factor for the renal dysfunction.
\end{abstract}

\section{Key words:}

Adiponectin, proteinuria, rats.

\section{Introduction}

Adiponectin is produced by adipose tissue and its serum concentration is reduced in obesity and systemic arterial hypertension. Some clinical studies have linked obesity and renal diseases to the adiponectin plasma concentration (1). Adiponectin has an anti-inflammatory and podocyte disruption profile, which has a negative correlation with proteinuria (1). The presence of protein in the urine may indicate infection or renal dysfunction. The spontaneously hypertensive rats (SHR) developed by Okamoto \& Aoki (2), exhibit a multifactorial profile extremely similar to the essential hypertension in humans (3) and present a lower percentage of adipose tissue when compared to their normotensive control, WistarKyoto (WKY) (4), while WKY exhibit higher adipose tissue percentage in relation to their control, Wistar (WIS) (5). SHR and WKY present higher urine protein concentrations when compared to WIS, indicating that proteinuria in SHR may be related to hypertension and in WKY due to the heavy weight and, possibly, the low adiponectin production (6). Therefore, we aimed to evaluate serum concentrations of adiponectin and its relation to proteinuria in WIS, WKY and SHR rats.

\section{Results and Discussion}

Blood samples were collected from the three strains at 15 weeks of life after 12-16h fasting. The results indicate a significant reduction in adiponectina serum concentrations WKY when compared to WIS and SHR. SHR exhibit similar serum adiponectin concentrations from WIS (Table 1). Adiponectin concentrations are inversely proportional to proteinuria and disrupts renal podocytes (1). Proteinuria indicates infection or renal dysfunction, where obesity, overweight and hypertension are the main risk factors for the development of renal diseases (7).
Table 1. Serum adiponectin concentration in WIS, WKY and SHR rats at 15 weeks of age.

\begin{tabular}{|c|c|c|c|c|}
\cline { 2 - 5 } \multicolumn{1}{c|}{} & Wistar & WKY & SHR & $p^{*}$ \\
\hline Adiponectin $(\mu \mathrm{g} / \mathrm{ml})$ & $28.53 \pm 2.619$ & $14.39+0.72^{*}$ & $29.90 \pm 3.25^{*}$ & 0.0011 \\
\hline
\end{tabular}

\section{Conclusions}

Proteinuria specifically refers to renal dysfunction in WKY and SHR. In WKY, the low adiponectin production is associated with the higher concentrations of proteins in the urine and the heavy weight of these animals $(5,6)$. In $\mathrm{SHR}$, serum adiponectin is not related to proteinuria, suggesting the hypertension as the responsible factor for the renal dysfunction (6).

\section{Acknowledgement}

FAPESP, FAEPEX, CAPES, SAE, PIBIC - CNPQ.

1. Ahima RS. Linking adiponectin to proteinuria. J Clin Invest 1182008. p. $1619-22$.

2. Okamoto K, Aoki K. Development of a strain of spontaneously hypertensive rats. Jpn Circ J. 1963;27:282-93.

3. Dornas WC, Silva ME. Animal models for the study of arterial hypertension. J Biosci. 2011;36(4):731-7.

4. Silva C, et. al. Peso corporal, ingesta hídrica e alimentar: avaliação em rato espontaneamente hipertenso e seu controle, o Wistar Kyoto. XIII Congresso Aberto aos Estudantes de Biologia 2017.

5. Morais C. L, et. al. Peso corporal, ingesta hídrica e alimentar entre ratos normotensos: Wistar e Wistar Kyoto. XIII Congresso Aberto aos Estudantes de Biologia 2017.

6. Silva C, et. al. Urinalysis of Wistar, Wistar Kyoto and Spontaneous Hypertensive Rats. XXV Congresso de Iniciação Científica da UNICAMP 2017.

7. Silva Junior GBD, et. al. Obesity and kidney disease. Brazilian Journal of Nephrology 2017. 